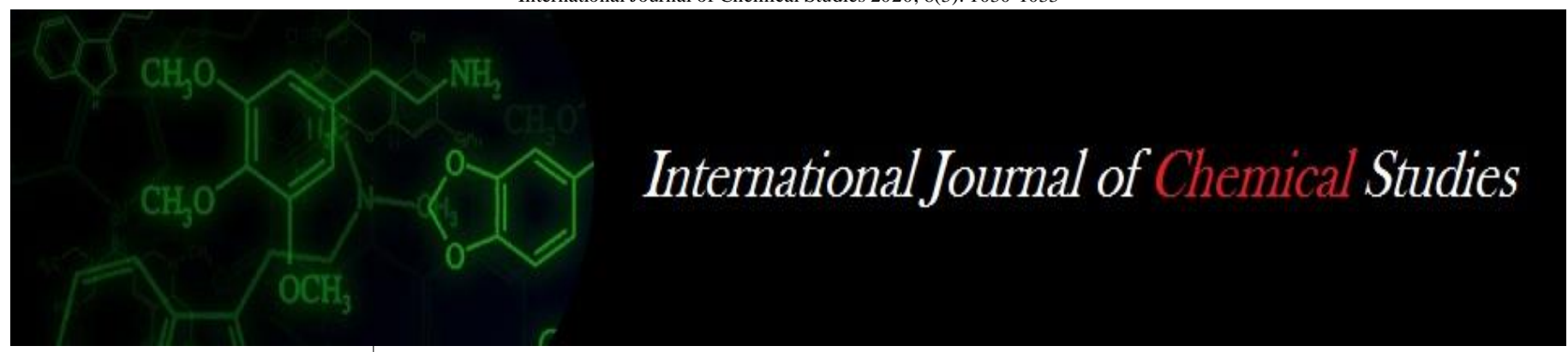

P-ISSN: 2349-8528

E-ISSN: 2321-4902

www.chemijournal.com

IJCS 2020; 8(3): 1030-1033

(C) 2020 IJCS

Received: 16-03-2020

Accepted: 18-04-2020

\section{Gharge PV}

Agricultural Development trust's, College of Agriculture, Baramati affiliated with Mahatma Phule Krishi

Vidyapeeth, Rahuri,

Maharashtra, India

\section{Karpe AH}

Agricultural Development trust's, College of Agriculture, Baramati affiliated with

Mahatma Phule Krishi

Vidyapeeth, Rahuri,

Maharashtra, India

\section{Patil PR}

Agricultural Development trust's, College of Agriculture, Baramati affiliated with Mahatma Phule Krishi Vidyapeeth, Rahuri, Maharashtra, India

Corresponding Author: Gharge PV

Agricultural Development trust's, College of Agriculture,

Baramati affiliated with

Mahatma Phule Krishi

Vidyapeeth, Rahuri,

Maharashtra, India

\section{Effect of split nitrogen application on growth parameters of maize}

\author{
Gharge PV, Karpe AH and Patil PR
}

DOI: https://doi.org/10.22271/chemi.2020.v8.i3m.9332

\begin{abstract}
A field experiment was designed to study the Effect of split nitrogen application on growth parameters of maize on research field of agricultural development trust, Baramati for two consecutive years during rainy season in 2017and 2018. An experiment was laid out in randomized complete block design with four replications. Four splits application of recommended dose of $\mathrm{N}$ were applied as $50 \% \mathrm{~N}$ at basal and $50 \% \mathrm{~N}$ at knee high stage (T1), 50\% $\mathrm{N}$ at basal, $25 \% \mathrm{~N} 30$ days after sowing and $25 \% \mathrm{~N}$ at tasseling stage (T2), 50\% $\mathrm{N}$ at basal and remaining nitrogen as per Leaf Colour Chart (T3) and 30\% $\mathrm{N}$ at basal, $30 \% \mathrm{~N}$ at 30 days after sowing and $30 \% \mathrm{~N}$ at tasseling stage (T4). Results showed that all studied parameters were significantly affected by application time of nitrogen. Experimental results exhibited that application of 50\% $\mathrm{N}$ at basal and remaining nitrogen as per Leaf Colour Chart (LCC) has produced maximum plant height, number of leaves per plant and cob length. Results of these studies revealed that, application of $\mathrm{N}$ fertilizers based on leaf colour chart, would be more economical to minimize $\mathrm{N}$ losses from the soil and efficient use of $\mathrm{N}$ at critical growth and development stages of maize.
\end{abstract}

Keywords: Maize; application time; nitrogen; leaf colour chart

\section{Introduction}

Maize (Zea mays L.) is the third most important grain crop in the world after wheat and rice. It has a great utility in agro industry. The cultivation of maize has been gaining popularity in recent years. It is now becoming an important cereal crop for its high productivity and diversified use. Maize being an exhaustive crop, its requirement for fertilizers is prominent. The productivity of maize largely depends on its nutrient requirement and management particularly that of nitrogen, phosphorus and potassium (Rasheed et al., 2004) ${ }^{[12]}$. Nitrogen is essential constituent of chlorophyll, protoplasm, and enzymes and it governs utilization of phosphorus and potassium. Efficient use of nitrogen by maize permits use of appropriate source in an adequate amount, at proper timing and suitable application rates (Rizwan et al., $2003)^{[14]}$. The utilization efficiency of added nitrogen fertilizer is very low, as applied nitrogen is subjected to various kinds of losses like leaching, volatilization and denitrification. The efficiency of applied $\mathrm{N}$ fertilizer not only depends on right quantity but also on right time, method of $\mathrm{N}$ application, crops and different genotypes of the same crops. Timing of $\mathrm{N}$ application is also deliberated as the best managing strategy and is very crucial for maize production (Walsh et al., 2006) ${ }^{[17]}$. However, split application of $\mathrm{N}$ can nourish the crop better through optimum $\mathrm{N}$ uptake and thus protects the environment from the adverse effect of these chemical inputs. Application timing of nitrogen in maize has a great importance and considered the best and appropriate for production of maize. In order to get maximum and appropriate vegetative growth and yield, increasing the nitrogen use efficiency by crop could be achieved through best management practices of nitrogen (Rehmati H., 2009) ${ }^{[13]}$. In recent years many precision tools are being used in the nitrogen management especially in maize. Among these leaf colour chart (LCC) is one of the precision tools. Leaf color charts (LCCs) are high quality a numbered series of plastic stips that range from yellowish green to dark green based on wavelength characteristic of leaves. By visual comparison, the panel value closest in color to a leaf indicates whether $\mathrm{N}$ is deficient, sufficient, or in excess (Friedman et al., 2016) ${ }^{[8]}$. The LCC used at critical growth stages help to adjust upward and/downward of the recommended dose of N rate based on leaf color (Bijay Singh et al., 2012) ${ }^{[4]}$. 
The main reason for low nitrogen use efficiency is inefficient splitting of $\mathrm{N}$ applications and use of $\mathrm{N}$ in excess to the requirements, which is analogous with uncertainty faced by the farmers in deciding fertilizer $\mathrm{N}$ to be applied. Keeping in view the importance of nitrogen application in splits doses on growth performance of maize, the present research studied was planned to study the effects of split $\mathrm{N}$ application on growth components of maize.

\section{Materials and methods}

Field trial was conducted at Research Farm of Agricultural Developement Trust, Baramati during Kharif seasons of 2017 and 2018 in medium black soil. The trials were laid down in a randomized block design having 4 treatments with 4 replications. The test variety of sweet corn maize was Sugar 75 a single cross hybrid. Plot size was 4 rows, 6 meters long, with plant spacing of $45 \times 20 \mathrm{~cm}, 1$ plant/hill. Recommended practices for disease and insect pest control were followed. Recommended dose of fertilizers for maize crop was 120:60:60 NPK kg/ha. Nitrogen was applied at graded levels as per the treatments in splits i.e.

$\mathrm{T} 1-50 \% \mathrm{~N}$ at basal and $50 \% \mathrm{~N}$ at knee high stage,

$\mathrm{T} 2-50 \% \mathrm{~N}$ at basal, $25 \% \mathrm{~N} 30$ days after sowing and $25 \% \mathrm{~N}$ at tasseling stage,

$\mathrm{T} 3-50 \% \mathrm{~N}$ at basal and remaining nitrogen as per Leaf Colour Chart (LCC),

$\mathrm{T} 4-30 \% \mathrm{~N}$ at basal, $30 \%$ at 30 days after sowing and $30 \%$ at tasseling stage.

Entire quantity of P2O5 and $\mathrm{K} 2 \mathrm{O}$ was applied as a basal dose. The sources of nitrogen, phosphorus and potassium were urea, single super phosphate and muriate of potash respectively. The split dose of nitrogen fertilizer was applied by placement at $5 \mathrm{~cm}$ away and $5 \mathrm{~cm}$ below the seed rows. Data collection started two weeks after the treatments were applied. Growth parameters recorded at 15, 30, 45, 60, 75 days after sowing and at harvest stage. Five plants were randomly selected per plot for determination of growth parameters. The growth parameters assessed included plant height $(\mathrm{cm})$ and number of leaves. The data recorded on hybrid maize for plant height and no. of leaves was statistically analyzed following the method of analysis of variance. The recorded data were statistically analyzed by SPSS version 20. Means were compared using LSD test at 0.05 level of probability, if the Fvalues are significant. Treatment differences that were non significant are denoted as NS.

\section{Result and discussion \\ Plant height (cm)}

The time of $\mathrm{N}$ application significantly affected plant height. It increased with increasing split application of nitrogen. So, the maximum plant height was obtained with the T3 treatment $(50 \% \mathrm{~N}$ at basal and remaining nitrogen as per Leaf Colour Chart (LCC) for all observations recorded at 15, 30, 45, 60, 75 days after sowing and at harvest stage, while the least values was recorded in plots of T4 $(30 \% \mathrm{~N}$ at basal, $30 \%$ at 30 days after sowing and $30 \%$ at tasseling stage) treatment application (Table 1). Split nitrogen application had significantly $(\mathrm{P} \leq 0.05)$ affected plant height of maize crop measured at different times except 30 days after sowing (Table 1). Anjum et al. (2018) ${ }^{[3]}$ reported maximum plant height from treatment of nitrogen application in three split 60 $\mathrm{kg}$ ha- 1 before sowing $+60 \mathrm{~kg}$ ha- 1 at knee height stage +60 $\mathrm{kg}$ ha-1 before tasseling stage in comparison with two split, $90 \mathrm{~kg}$ ha- 1 at sowing $+90 \mathrm{~kg}$ ha-1 at knee height stage and single application of nitrogen $180 \mathrm{~kg}$ ha- 1 before sowing. The plant height increased with more nitrogen splits application. It may be due to supply of proper amount of $\mathrm{N}$ at different growth stages of maize. The $\mathrm{N}$ promotes plant growth, increase the number and length of internodes which resulted in taller plants of maize crop (Adhikari et al., 2016) ${ }^{[1]}$. Similarly, almost similar results were found with more $\mathrm{N}$ splits as compared to lesser no. of N splits (OSU, 2016) ${ }^{[11]}$. Jat et al., (2013) ${ }^{[9]}$ reported that sequential applications of $\mathrm{N}$ just prior to planting with starter fertilizer at a rate of $30 \mathrm{~kg} \mathrm{~N}$ ha-1 and split applications at knee height stage, and at the time of flowering stage can be an effective $\mathrm{N}$ delivery system. Thakur et al. (1997) ${ }^{[16]}$ suggested that higher $\mathrm{N}$ application increased cell division, cell elongation, nucleus formation as well as green foliage. Increase in plant height may also be due to prolonged vegetative growth which increased the plant height. Castro et al. (2008) ${ }^{[5]}$ reported that plant height is influenced by the availability of $\mathrm{N}$ in the soil since this nutrient participates directly in photosynthetic process and cell division and expansion. Gross et al. (2006) [7] recommended that $\mathrm{N}$ should be applied in one or two application during the season only, due to the positive effects on plant height. However, it is worth noting that plant height does not always correlate with productivity since modern hybrids with high productive potential are mostly of lower height (Cruz et al., 2008) ${ }^{[6]}$.

Table 1: Effect of different nitrogen application timings on plant height of maize

\begin{tabular}{|c|c|c|c|c|c|c|}
\hline Treatments & \multicolumn{5}{|c|}{ Plant Height (cm) } \\
\cline { 2 - 7 } & $\mathbf{1 5}$ DAS & 30 DAS & 45 DAS & 60 DAS & 75 DAS & Harvest Stage \\
\hline T1 = 50\% N basal + 50\% N knee high stage & $16.59^{\mathrm{a}} \mathrm{b}$ & 66.70 & $160.00^{\mathrm{a}}$ & $189.75^{\mathrm{a}}$ & $201.25^{\mathrm{a}}$ & $205.25^{\mathrm{a}}$ \\
\hline $\mathrm{T} 2=50 \% \mathrm{~N}$ basal + 25\% N 30 DAS + 25\% N tasseling & $18.02^{\mathrm{a}}$ & 68.40 & $156.50^{\mathrm{a}}$ & $186.25^{\mathrm{a}}$ & $197.20^{\mathrm{a}}$ & $201.20^{\mathrm{a}}$ \\
\hline T3 = 50\% N basal + Remaining N as per LCC & $18.02^{\mathrm{a}}$ & 70.30 & $172.35^{\mathrm{b}}$ & $202.10^{\mathrm{b}}$ & $213.75^{\mathrm{b}}$ & $217.75^{\mathrm{b}}$ \\
\hline $\mathrm{T} 4=30 \% \mathrm{~N}$ basal + 30\% N 30 DAS + 30\% N tasseling & $15.25^{\mathrm{b}}$ & 65.10 & $141.60^{\mathrm{c}}$ & $171.35^{\mathrm{c}}$ & $182.65^{\mathrm{c}}$ & $186.65^{\mathrm{c}}$ \\
\hline Mean & 16.97 & 67.63 & 157.61 & 187.36 & 198.71 & 202.71 \\
\hline SD & 3.67 & 9.07 & 21.20 & 21.34 & 21.46 & 21.46 \\
\hline SE of mean & 0.41 & 1.01 & 2.37 & 2.39 & 2.40 & 2.40 \\
\hline P - value & 0.045 & 0.306 & 0.000 & 0.000 & 0.000 & 0.000 \\
\hline LSD at 5\% & Significant & NS & Significant & Significant & Significant & Significant \\
\hline
\end{tabular}

Data within columns followed by different letters are significantly different at $\mathrm{P}<0.05$.

\section{No. of leaves per plant}

It can be inferred from the data showed that time of application of nitrogen at different growth stages had significant effect on number of leaves plant per plant of maize at 30, 45, 60, 75 days after sowing. However, time of application of nitrogen found non-significant with number of leaves per plant at 15 days after sowing. Maximum number of leaves plant per plant was recorded from T3 treatment which is statistically at par with T1, T2 and T4 treatment (Table 2). Split application of $\mathrm{N}$ had significant effects on the leaf 
number per plant (Amanullah et al., 2009) ${ }^{[2]}$. The increase in the number of leaves per plant could possibly be ascribed to the fact that nitrogen often increases plant growth and plant height and this resulted in more nodes and internodes and subsequently more production of leaves. Number of leaves per plant was recorded as 13.9 with application at the rate of $150 \mathrm{~kg}$ ha-1 and 12.3 with no $\mathrm{N}$ application after 90 DAS (Kaur et al. 2015) ${ }^{[10]}$. The increase in number of leaves per plant with each increment of nitrogen level might be attributed to increase in plant height and better crop growth.

Table 2: Effect of different nitrogen application timings on number of leaves per plant and cob length (cm) of maize

\begin{tabular}{|c|c|c|c|c|c|c|}
\hline Treatments & \multicolumn{4}{|c|}{ No. of Leaves per plant } & \multirow{2}{*}{ Cob length (cm) } \\
\cline { 2 - 7 } & 15 DAS & 30 DAS & 45 DAS & 60 DAS & 75 DAS & \\
\hline T1 = 50\% N basal + 50\% N knee high stage & 6.45 & $9.90^{\mathrm{ab}}$ & $12.10^{\mathrm{a}}$ & $14.80^{\mathrm{a}}$ & $17.80^{\mathrm{a}}$ & $13.70^{\mathrm{a}}$ \\
\hline $\mathrm{T} 2=50 \% \mathrm{~N}$ basal + 25\% N 30 DAS + 25\% N tasseling & 6.30 & $9.80^{\mathrm{ab}}$ & $11.85^{\mathrm{a}}$ & $14.60^{\mathrm{a}}$ & $17.60^{\mathrm{a}}$ & $13.81^{\mathrm{a}}$ \\
\hline T3 =50\% N basal + Remaining N as per LCC & 6.30 & $10.40^{\mathrm{a}}$ & $13.95^{\mathrm{b}}$ & $18.70^{\mathrm{b}}$ & $23.45^{\mathrm{b}}$ & $18.70^{\mathrm{b}}$ \\
\hline $\mathrm{T} 4=30 \% \mathrm{~N}$ basal + 30\% N 30 DAS + 30\% N tasseling & 6.20 & $9.40^{\mathrm{b}}$ & $11.55^{\mathrm{a}}$ & $13.80^{\mathrm{c}}$ & $16.55^{\mathrm{c}}$ & $16.09^{\mathrm{c}}$ \\
\hline Mean & 6.31 & 9.88 & 12.36 & 15.48 & 18.85 & 15.58 \\
\hline SD & 0.52 & 1.08 & 1.34 & 2.18 & 2.92 & 2.37 \\
\hline SE of mean & 0.06 & 0.12 & 0.15 & 0.24 & 0.33 & 0.26 \\
\hline P - value & 0.505 & 0.031 & 0.000 & 0.000 & 0.000 & 0.000 \\
\hline LSD at 5\% & NS & Significant & Significant & Significant & Significant & Significant \\
\hline
\end{tabular}

Data within columns followed by different letters are significantly different at $\mathrm{P}<0.05$.

\section{Cob length $(\mathbf{c m})$}

Nitrogen applications in split have significant $(\mathrm{P} \leq 0.05)$ effect on cob length. Maximum cob length was observed from T3 treatment application $(50 \% \mathrm{~N}$ at basal and remaining nitrogen as per Leaf Colour Chart (LCC)) followed by T4 treatment $(30 \% \mathrm{~N}$ at basal, $30 \%$ at 30 days after sowing and $30 \%$ at tasseling stage). Lowest cob length was recorded from $\mathrm{T} 1$ and T2 treatment (Table 2). Maximum cob length at more split application of nitrogen has decreased nitrogen loses and provided an adequate amount of nitrogen to the plant which showed more increase in vegetative growth and hence increased length of cob. Our results were strongly in agreement with Anjum et al. (2018) ${ }^{[3]}$, who reported that highest cob length was observed from treatment of nitrogen in three split application ( $60 \mathrm{~kg}$ ha- 1 before sowing $+60 \mathrm{~kg}$ ha1at knee height stage $+60 \mathrm{~kg}$ ha-1 before tasseling stage) followed by two splits. Similarly, highest cob length in nitrogen fertilizer plots and smallest cob length in the plots where nitrogen was not applied reported by Sharifi SR \& Taghizadeh (2009) ${ }^{[15]}$.

\section{Conclusion}

In our study it was observed that split application of $\mathrm{N}$ rates led to increased $\mathrm{N}$ availability, which possibly increased the plant height, number of leaves per plant and cob length. Timing of $\mathrm{N}$ application is also deliberated as the best managing strategy and is very crucial for maize production. Time of application significantly enhances $\mathrm{N}$ absorption, particularly at the time of critical $\mathrm{N}$ requirement for the crop. It was concluded from the research that nitrogen application in split as per requirement of crop i.e. $50 \% \mathrm{~N}$ at basal and remaining nitrogen as per Leaf Colour Chart (LCC) gave better results.

\section{References}

1. Adhikari P, Baral BR, Shrestha J. Maize response to time of nitrogen application and planting seasons. J Maize Res Develop. 2016; 2(1):83-93.

2. Amanullah, Riaz A Khattak, Shad K Khalil. Plant Density and Nitrogen Effects on Maize Phenology and Grain Yield, Journal of Plant Nutrition. 2009; 32(2):246260.

3. Anjum MM, Shafi M, Ahmad H, Ali N, Iqbal MO, Ullah $\mathrm{S}$ et al. Influence of split nitrogen application on yield and yield components of various maize varieties. Pure and Applied Biology. 2018; 7(2):721-726.

4. Bijay-Singh, Yadvinder-Singh, Ladha JK, Bronson KF, Balasubramanian V, Singh J, Khind CS. Chlorophyll meter and leaf color chart based nitrogen management for rice and wheat in northwestern India. Agron J. 2002; 94:821-29.

5. Castro PRC, Kluge RA, Sestari I. Manual of plant physiology: Crop physiology. (In Portuguese.) Agronômica Ceres, São Paulo, Brazil, 2008, 864p.

6. Cruz SCS, Pereira FRS, Santos JR, Albuquerque AW, Silva ET. Split application of nitrogen in irrigated maize crop under no-tillage system. (In Portuguese, with English abstract.) R. Bras. Eng. Agrí. AMB (Sao Paulo). 2008; 12:370-375.

7. Gross MR, Pinho RGV, Brito AH. Nitrogen fertilization, sowing rate and interrow spacing in maize crop in notillage system. (In Portuguese, with English abstract.) Cienc. Agrotec. 2006; 30:387-393.

8. Friedman JM, Hunt ER, Mutters RG. Assessment of leaf color chart observations for estimating maize chlorophyll content by analysis of digital photographs Agronomy journal. 2016; 108(2):822-829.

9. Jat ML, Satyanarayana T, Manundar K, Parihar CM, Jat SL, Tetarwal JP et al. Indian Journal of Fertilizer. 2013; 9(4):80-94.

10. Kaur J, Vashisht KK. Influence of Nitrogen levels, irrigation regimes and planting methods on growth attributes and yield of spring maize Agricultual Research Journal. 2015; 52(1):13-18.

11. OSU. Oklahoma State University. Information on world maize production. Retrieved from, 2016. http://nue.okstate.edu/Crop_Information/World_Maize_P roduction.htm

12. Rasheed M, Mahmood T, Nazir MS, Bhutta WA, Ghaffer A. Nutrient efficiency and economics of hybrid maize under different planting methods and nutrient levels. International Jourl. of Agriculture and Biology. 2004; 06(5):922-925.

13. Rehmati H. Effect of plant density and nitrogen rates on yield and nitrogen use efficiency of grain corn. Applied Sci J. 2009; 7(8):958-961.

14. Rizwan M, Maqsood M, Rafiq M, Saeed M, Ali Z. Maize (Zea mays L.) response to Split application of Nitrogen. Intl J Agric Biol, 2003, 1560-8530. 
15. Sharifi SR, Taghizadeh. Response of maize (Zea mays L.) cultivars to different levels of nitrogen fertilizer. J Food Agric Environ. 2009; 7(3):518-521.

16. Thakur DR, Prakash O, Kharwara PC, Bhalla SK. Effect of nitrogen and plant spacing on yield, nitrogen uptake and economics in baby corn (Zea mays L.). Indian $\mathbf{J}$ Agron. 1997; 43(4):668-71.

17. Walsh OS. Effect of Delayed Nitrogen Fertilization on Corn Grain Yields. M. Sc. Thesis. Graduate College. Oklahoma State Uni., Oklahoma, 2006. 